\title{
Education during the Arab Renaissance and Its Path to the West
}

\author{
LOULOU AL-AKL KHOURY 1
}

\begin{abstract}
Islam was at the origin of schools, during the Umayyad and Abbasid periods, as every Moslem had to know how to read the Koran. In different regions, namely Spain, public schools were free, and education went beyond the teaching of the Scriptures. Propagating ideas read or heard was equivalent to an aptitude certificate. This approach led to the right of the author and was transmitted to universities in the West as well as the works of ancient philosophers and scientists. When The Christian Front Union disintegrated, alliances with Moslem princes were common. Hence, Arab teachers were in charge of educating the royal children of Aragon, and physicians were called at the bedside of patients among other functions. The school of translation established in Toledo by Bishop Raymond comprised a collection of scientific and literary Arab work that enlightened spirits of European countries. The fall of the Andalusias in the XV century marked the end of a perennial civilization. Yet, students are still taught had not Charles Martel beaten the Arabs, nothing would have survived.
\end{abstract}

Keywords: Al-Andalus, Arab Renaissance, education, Sigrid Hunke, Western education

Education during the Arab Renaissance and its Path to the West is the 3rd article of the series titled Hospitals and Doctors during the Arab Renaissance and Pharmacists and Medicine during the Arab Renaissance Periods both published 2016, summarized and translated from the book, Le Soleil d'Allah brille sur l'Occident by Sigrid Hunke (1977) written in German and translated to French by Solange and Georges de Lalène and published by Albin Michel.

When one thinks of the $9^{\text {th }}-12^{\text {th }}$ centuries, central Europe counted $95 \%$ of illiterate people. In monasteries, few monks knew how to write. In the meantime, in thousands of schools in Arab cities and villages, boys and girls (aged 6 to 11), crouched on their small carpets, sketched letters of the alphabet on their polished board or spelled the verses of the Quran until they learned how to chant the surahs by heart, and slowly initiated themselves at the rudiments of grammar.

Islam was at the origin of those schools. They were born spontaneously, without anyone ordering their creation. Every Moslem had to know how to read the Holy Scriptures whereas, in the West, only priests had access to the Holy Christian Scriptures whose reading was forbidden to the laymen (Hunke 1977: 241).

At this period, Christians did not feel the necessity to read and write, and further responsible people did not wish to educate them. In the Moslem world, children of all social statuses went to primary schools, for a small sum of money. In different regions, namely Spain, public schools were fully free. In addition to the 80 public schools that already existed in Cordova, Al-Hakam II in 965 A.D. established 27 new schools for poor children. In Cairo, Al-Mansour Qalaouin established a school for orphans at the Mansouri Hospital and required for every child 'one daily loaf of bread, one winter clothe and one for summer.'

${ }^{1}$ Loulou al-Akl Khoury, Ph.D., former lecturer at the Lebanese American University (LAU) and the American University of Beirut (AUB), 501 Street, BIKFAYA, Lebanon, email: loulou.aklkhoury@outlook.com.

https://doi.org/10.24035/ijit.16.2019.006 
Education of the Arab people went beyond the elementary level, and politics was the generator of this progress. It was at this stage that the ambitious Arab youth was initiated at the Koran, traditions, grammar, philology, rhetoric, literature, history, ethnology, logic, mathematics and astronomy. Through questions and discussions, students took active roles in lessons. Helpers and assistants chosen among students, who finished or at the verge of ending their studies, helped students review what the teacher taught them.

More than one peasant entrusted his son to a master living in the city who boarded the child in exchange of money or food. The teacher promised to make out of the student, depending on his abilities, a candidate for a public function such as a future cadi or perhaps an officer at the court. The student made himself useful at home, did the shopping in the souks, and as a trustworthy squire, followed his master to the hammam or the mosque. Other fathers taught their children at home by providing tutors. A prodigal son such as Ibn-Sina, who at 10 years, knew the Koran and many works of philology, would have bypassed the scholar system (Hunke 1977: 242-243).

The usual path taken by the one who wanted to deepen his knowledge, in a subject well determined so as to teach, led him to the mosque. The mosque was not a place for prayer only. It also shaded science that, according to the Prophet, enthroned above blind devotion. 'Learning of a student is more sacred than the blood of a martyr,' said the Prophet (Hunke 1977: 244).

Under the arches of the mosque, the student always had the occasion to listen to the conferences of eminent visiting scholars who often came from faraway regions of the Arab Empire. These scholars grabbed the occasion to give a conference at the mosque Al-Azhar in Cairo, Karaouin in Fez or Zeitouna in Tunis. These travelers spread, to the world, the new ideas. When these ideas were explained during a public session, listeners, who based their lessons on the work of a scholar, needed his written approval, recounted Yahya bin-Issa who heard Abu Bakr al-Baghdadi told what Sheikh Saïd ben-Yäqout had explained during a public session (Hunke 1977: 245).

Thus, authorization to propagate ideas read or heard was equivalent to an aptitude certificate obtained by the students. Whoever obtained such a license obtained simultaneously the right to teach in public: licentia docendi. This is how the 'right of the author' was transmitted through schools to universities in the West. It is the origin of the academic rank, license-holder and probably the baccalaureate too, bihaq-ar-riāya of the Arabs (the right to teach under the authority of another).

Arab universities spread since the IX century and attracted a wave of illegal visitors, who came from beyond the Pyrenees, and gave the West a model of temporary scientific institution, whether concerning the method of teaching university degrees or the division of university faculties. Besides the means of teaching, Arabs transmitted subjects to teach (Hunke 1977: 246). In fact, Arabic language became the language of the learned. Scholars, researchers and students headed to Cordova to learn the language which would provide them with ample learning opportunities. Later on, the Western scholars would translate the works of Muslim scholars during the $7^{\text {th }}$ and $8^{\text {th }}$ centuries, providing the foundation of scholarship (El-Kaidi 2018).

Further, the Arabs transmitted to posterity the works of ancient philosophers and scientists. However, the western intermediaries made the error of omitting the go-between. The Greeks as well as the Indians were already intermediaries. Thales and Pythagoras, who acquired their knowledge of mathematics and astronomy through Egyptians and Babylonians, had already considered themselves as the creators of those rules. Every period seized, the scientific existing belonging, and transformed it according to their laws. Thales recognized in the geometrical rules of the Egyptians, the universal theorems. And yet, all Arab and Western civilizations have their own proper means of expressing the original and unconvertible work of their creators (Hunke 1977: 247).

Through experience and observation, Arabs developed the scientific giving's of the Greeks and were the creators of experimental research. They took isolated facts in their context as the 
starting point of all research. Hence, the inductive method became the fundamental scientific method (Hunke 1977: 248). A wide range of experiments, practiced methodically and repeated with infinite patience, allowed to test, then rectify the ideas generally admitted. This was due to the audacious independence of thinking and investigation that, eight centuries earlier than the West, manifested itself in the following terms: 'Doubt is the preliminary condition of knowledge' (Hunke 1977: 248). One of the first great western emperors, who was influenced by the lively Arab spirit and who was not worried of associating himself with them, was Emperor Frederic II of Hohenstaufen (Hunke 1977: 249).

\section{The Path to the West}

It was long time ago that The Christian Front Union against Islam disintegrated. The internal fights of the Christian leaders for power had weakened the unanimity that was basic against the common enemy, Islam. This was how the alliances with Moslem princes overthrew religious barriers (Hunke 1977, 372). An obvious example is the true story behind the legend of the military leader Rodrigo Diaz de Vivar (1043-1099) surnamed EL Cid, meaning the leader. He was a Castilian nobleman, military leader and diplomat. Expelled from the court of the Spanish Emperor Alfonso VI of Leon and Castile, he went to command a Moorish force under Yusuf- al Mu'taman ibn-Hud, a Moorish king of northeast Al-Andalus city of Zaragoya (Barton \& Fletcher 2000). In fact, Corneille, the 17th century French writer, wrote his tragedy Le Cid based on Rodrigo Diaz de Vivar.

More than a century had passed since the Bishop of Cordova, Alvaro, expressed his bitter complaint: 'Many of my co-religionists read Arabic poetry and short stories, study the work of Moslem theologians and philosophers, not to refute them, but to learn to express themselves correctly and elegantly in the Arabic language. Where do we still find today a layman who reads the commentaries of the Holy Scripture in Latin? Who among the laymen study the Gospels, the Books of the Prophets or the Apostles?' (Hunke 1977: 373).

Through many centuries of fight against the Arabs of Al-Andalus, and in spite of the fact that by mid-13 ${ }^{\text {th }}$ century, the Emirate of Granada was the only independent Muslim realm in Spain but a vassal state of Castile, to which it paid tribute, 'the Spanish spirit was still strongly influenced by Islam' (Hunke 1977: 374). Because of continuous overturns of alliances, among Northern Spain and Al-Andalus, weddings among the nobility and common people became common (Hunke 1977: 375). It was Arab teachers that were in charge of educating the royal children of Aragon, it was Arab physicians that were called at the bedside of patients, and it was Arabs that occupied the functions of scribes in the royal secretarial staff. It was Arab civil servants at the court that influenced the way of life at Barcelona, Burgos and Lisbon (Hunke 1977: 376). Finally, Abd al-Malik, the fifth caliph of the Umayyad dynasty, reformed and arabized the diwann, the internal administrative reforms of the empire, and created the new currency which was up till that time still using the Byzantine coins of the realm in the west, and Sasanian coins in the east (Saliba 2011).

The school of translation in Toledo established by Bishop Raymond from (1126-1151) at the library of the Cathedral of Toledo had a team of translators who included Mozarabic Toledans (Arabic-speaking Christians), Jewish scholars, Madrasah teachers and monks from the Order of Cluny. They translated many works, usually from Arabic into Castilian and from Castilian into Latin, as it was the official church language. The work of these scholars made available very important texts from Arabic and Hebrew philosophers (Haskins 1924). This school of translation had also a precious collection of scientific and literary Arab work that attracted for many centuries, such as a magnet, the enlightened spirits of all European countries (Hunke 1977: 376). Whether it was merchants, scholars or physicians, they all brought back to the West the results of Arab Science and Literature and

https://doi.org/10.24035/ijit.16.2019.006 
contributed to a large extent in the translation of the work undertaken by Bishop Raymond as well as its spreading (Hunke 1977: 377). As a result, the library of the cathedral, which had been refitted under Raymond's orders became a translation centre of a scale and importance not matched in the history of western culture (Burnett 1994).

In the $15^{\text {th }}$ century, the fall of Cordoba, Valencia, Seville and the other centres of the Moorish world, taken back from the Arabs, marked the end of a perennial civilization of the European continent during the Middle-Ages (Hunke 1977: 381). The scientific and literary Arabic treasures were snatched from libraries and hiding places and fed to the flames. Only a few medical works were spared. The zealots could be proud to have destroyed 1500000 volumes: the fruit of eight centuries of intellectual creation ludicrously sacrificed to hatred (Hunke 1977: 382). Further, as the economic, social and intellectual statuses of the modern man is evaluated through the value of his car and TV set, the value of the Arab between the $9^{\text {th }}$ and $13^{\text {th }}$ centuries were valued according to the quantity of books he owned (Hunke 1977: 235).

However, students were and still are taught, had Charles Martel not beaten the Arabs at war, the horde of Arab riders, swords brandished would have left trampled fields, dwellings razed to the ground and nothing would have survived, where the sinister shadow of the desert had passed (Hunke 1977: 388). And yet, the Umayyad and Abbasid periods were hardly mentioned. When a victorious state had the habit of including in the condition of the peace treaty the surrender of armaments and warships to the enemy, Harun al-Rashid, the Abbasid Caliphate, after the conquest of Amorium and Ankara, required no more than the hand-over of all ancient Greek manuscripts. Likewise, the Byzantine Emperor Constantine VII, who gained a reputation as a great scholar and a collector of books and manuscripts, considered the best way to get an alliance with the Caliph of Andalusia, Abd. al-Rahman III, whose reign became the most important intellectual centre of Western Europe (Encyclopedia Britanica 2010), was to send him a trunk of old manuscripts among which figured the Pharmacology of Dioscorides (Hunke 1977: 227).

This manuscript was written between 50 and 70 AD by a Greek physician in the Roman army. It is a five-volume book in Greek, known more widely in Western Europe by its Latin titled De Materia Medica. The book became the principal reference work on pharmacology across Europe and the Middle East for over 1500 years, and thus was the precursor of all modern pharmacopoeias. It was circulated in Latin, Greek and Arabic. Densely illustrated Arabic copies survived from the $12^{\text {th }}$ and $13^{\text {th }}$ centuries (Sutton \& Huxley 2007).

To conclude, wouldn't be more fruitful in the $21^{\text {st }}$ century, to make the Arab people aware of their past and guide them towards its identification? That is, their knowledge in the construction of hospitals, the existence of medical insurance, the use of anaesthetic and the treatment of psychic patients, while Europe drowned in the Dark Ages (Al-Akl Khoury 2016). Wouldn't be more educational to make the Arabs aware of their pharmaceutical knowledge and experiment on new drugs which became part of Western pharmacopoeia? They were the inventor of experimental research, and they considered doubt as the preliminary condition of knowledge (Al-Akl Khoury 2016). Those who have not integrated the Western societies, those whose existence have been forgotten could identify with their past, overcome their association with terrorists and not forget that the Prophet said, 'knowledge enthroned above devotion'. And yet, history, until the present, has a selective and short memory. 


\section{References}

Ak-Akl Khoury, L. 2016. Hospitals and Doctors during the Arab Renaissance. Lebanese Medical Journal (LMJ) 64(1): 60-62.

Ak-Akl Khoury, L. 2016. Pharmacists and Medicine during the Arab Renaissance Periods. World Journal of Pharmaceutical and Medical Research 2(4): 32-34.

Barton, S \& Fletcher, R. 2000. The World of EL Cid: Chronicles of the Spanish Reconquest. Manchester, UK: Manchester University Press in Wikipedia.org/wiki/El-Cid 2019. Retrieved: 18 August, 2019.

Burnett, C. 1994.Arabic-Latin Translation Program in Toledo, pp. 249-52, 270 in wikipedia.org/wiki/Toledo-School-of-Translation. Retrieved: 18 August, 2019.

El-Kaidi, Y. 2018. Arab Intellectual Leadership in Islamic Cordova: When Arabs were a Beacon of Light in the Dark Ages. https://insidearabia.com/arab-islamic-cordova-beacon-dark-ages. Retrieved: 18 August, 2019.

Encyclopededia Britanica 2010, pp. 17-18 in wikipedia.org/wiki/abd-al Rahman III. Retrieved: 18 August, 2019.

Haskins, C.H. 1924. Studies in Mediaeval Science. Cambridge: Harvard University Press.

Hunke S. 1977. Le Soleil d'Allah brille sur l'Occident. Paris: Albin Michel.

Saliba, G. 2011. Islamic Science and the Making of the European Renaissance. Cambridge: The MIT Press.

Sutton, David; Robert Huxley (ed.). 2007. Pedanios Dioscorides: Recording the Medicinal Uses of Plants. The Great Naturalists, pp. 32-37. London: Thames \& Hudson, with the Natural History Museum.

Wikipedia. Toledo School of Translators. https://en.wikipedia.org/wiki/Toledo_School_of_Translators. Retrieved: 18 August, 2019. 